THE polymorphonuclear neutrophils (PMN) possess sufficient potential to affect both immune response and inflammation, however it has not been yet described in the course of multiple sclerosis (MS). We have studied binding of fluorescein isothiocyanate (FITC) - stained TNF- $\alpha$ by PMN, the expression of CD11a, CD11b, and CD18 molecules of $\beta 2$-integrines and the expression of CD10 (neutral endopeptidaseNEP) and of CD13 (aminopeptidase N; APN) antigens on PMN in three different groups of MS patients. The control group included neurological patients (OND) with noninflammatory diseases. The obtained results have proved that during MS exacerbation and in the course of chronic progressive MS, PMN reveal several forms of preactivation, in cluding significantly higher stained-TNF- $\alpha$ binding, higher expression of CD11b and CD18, as well as CD10 and CD13 antigens, in comparison with MS remission or OND. We suggest that the increased expression of these molecules on PMN of MS patients in exacerbation of the disease and to a lower degree in the course of CP-MS is a result of PMN priming, and directly prove the PMN involvement in the disease pathogenesis.

Key words: Multiple sclerosis, Neutrophils, Tumour necrosis factor, Tumour necrosis factor receptors, Integrins, Proteases

\section{The immunoregulatory abilities of polymorphonuclear neutrophils in the course of multiple sclerosis}

\author{
J. Ząaber, ${ }^{1, C A}$ J. Paśnik, ${ }^{2}$ Z. Baj, ${ }^{2}$ L. Pokoca, ${ }^{3}$ \\ H. Chmielewski ${ }^{1}$ and H. Tchórzewski ${ }^{4}$
}

Departments of ${ }^{1}$ Neurology; ${ }^{2}$ Pathophysiology; ${ }^{3}$ Clinical Immunology Military Medical Academy, ul. Ž́eromskiego 113, 90-549 Lódź; ${ }^{4}$ Department of Clinical Immunology of Polish Mother's Health Institute, Lódź, Poland

${ }^{\mathrm{CA}}$ Corresponding Author

Tel/Fax: (+48) 426365282

\section{Introduction}

Multiple sclerosis (MS) is a disease in which multifocal inflammation and damage of the blood-brain barrier and myelin sheath are salient pathologic features. Overwhelming evidence demonstrates that MS is a predominantly T-cell and monocyte/macrophagemediated autoimmune disorder. ${ }^{1,2}$ Polymorphonuclear ne utrophils (PMN) have not been considered as a cell population participating in it. ${ }^{3} \mathrm{PMN}$ can however express immunoregulatory abilities, that has not been yet described in the course of MS. Activated in vitro PMN produce a number of immune mediators including cytokines like IL-1 $\beta$, IL-4, IL-6, IL-8, IL-10, IL-12, TNF, TGF $-\beta 1 .{ }^{4,5}$ Therefore the regulatory functions of these cells may be postulated in the course of MS.

PMN in the peripheral blood (PB) of MS patients can be primed mainly by inflammatory cytokines like IL-1, INF- $\gamma$, or by TNF- $\alpha$ secreted by mononuclear cells. Hypothetically PMN priming or activation in $\mathrm{PB}$ of MS patients may depend also on complement (especially C5a) immunological complexes, or certain metabolites of the arachidonic acid ( $\left.\mathrm{LTB}_{4}, \mathrm{PAF}\right)$.

Priming results in the enhanced expression on PMN of receptors for chemokines and other chemotactic peptides, ${ }^{6}$ priming also enhances the expression of CD11b/CD18 molecules on PMN cell surface $e^{7,8}$ w hich results in the indirect activation of PMN. ${ }^{9,10}$ In the presented paper we have suggested that PMN priming can be observed in MS patients peripheral blood.

\section{Patients and methods}

Patients (34 total; 19 women and 15 men, aged 22-56 years) were selected with a clinically definitive diagnosis of $\mathrm{MS}^{11}$ and with Kurtzke Expanded Disability Status Scale ${ }^{12}$ scores 5 or fewer and categorized as having the relapsing-remitting MS (RR-MS) course for at least 5 years but currently in remission (REM) $(n=13)$, as having either secondary CP-MS for at least 2 years $(n=13)$ or RR-MS and currently experiencing clinical exacerbation (REL) of the disease $(n=12)$. Exacerbations were defined as the appearance of new symptoms or significant worsening of the old ones, attributable to MS, for at least 24 hours without any fever.

The control group consisted of patients with other ne urological diseases (OND) (14 total; nine women and five men, aged from 24 to 37 years), including those with vasomotor headache $(n=8)$ and ischialgia $(n=6)$.

\section{Sample collection}

The studies were performed on PMN of the peripheral venous blood, collected into heparin-containing tubes $(10 \mathrm{U} / \mathrm{ml})$. 


\section{TNF labelling with fluorescein isothiocyanate} (FITC)

The synthesis and biological analysis of the TNF molecules were performed at the Department of Bioorganic Chemistry, Lódź, Poland (Patent No. 168858). TNF staining was done with FITC (Serva), according to Shirakawa et al. ${ }^{13} 100 \mathrm{mg}$ of FITC and $100 \mu \mathrm{l}$ of $0.2 \mathrm{M}$ carbonate buffer $(\mathrm{pH}=9.2)$ were added to $400 \mu \mathrm{g}$ of TNF, diluted in $400 \mu \mathrm{l}$ of PBS and then, incubated for $6 \mathrm{~h}$ at $4^{\circ} \mathrm{C}$. The labelled TNF w as separated from the non-labelled with FITC by gel filtration on a $3.5 \mathrm{~cm}^{3}$ column, filled with Sephadex G-25. TNF labelled FITC (TNF-FITC) was sterilized by filtration, using a $0.22 \mu \mathrm{m}$ filter and then, stored at $4^{\circ} \mathrm{C}$. The staining efficiency was measured, taking into account the absorbency at $280 \mathrm{~nm}$, in comparison with the absorbency at $495 \mathrm{~nm}$. The investigations were performed within 10 days after the TNF labelling due to relatively low stability of the labelling.

\section{Evaluation of TNF-FITC binding to PMN}

One hundred $\mu$ l of the whole blood was incubated with TNF-FITC at the concentration of $1000 \mathrm{ng} / \mathrm{ml}$ for $2 \mathrm{~h}$ at $4^{\circ} \mathrm{C}$. The erythrocytes were lysed, using $1 \mathrm{ml}$ of FACS Lysing Solution (Becton Dickinson) for $15 \mathrm{~min}$ at room temperature. Cells were centrifuged for $5 \mathrm{~min}$ at $400 \times \boldsymbol{g}$, then washed with $3 \mathrm{ml}$ of PBS and suspended in $100 \mu \mathrm{l}$ of PBS. The fluorescence intensity of PMN was measured using a flow cytometry FACScan (Becton Dickinson) and Lysis II software. Each measurement was repeated four times and presented here as a mean fluorescence intensity (MFI). Specificity of the binding of TNF-FITC to PMN was evaluated in blocking experiment by preincubation of the PMN with non-stained TNF in excess for $45 \mathrm{~min}$ before TNF-FITC binding (Fig. 1).

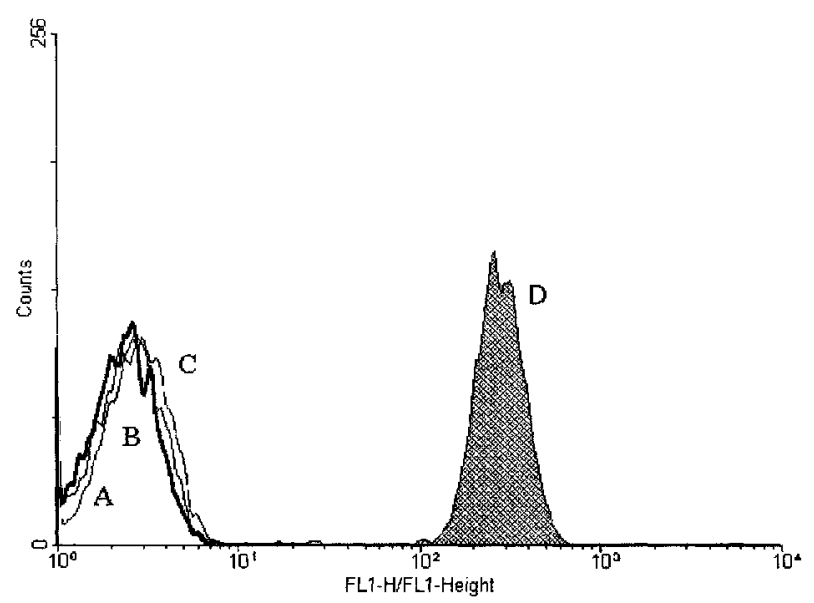

FIG. 1. Flow cytometric analysis of the TNF-FITC binding to PMN. Non-stained TNF added in 1000 times excess (C), significantly diminished MIF corresponding to nonspecific binding of control lgG-FITC (A) and lgG-FITC + non-stained TNF (B). The result (D) proves specificity of the TNF-FITC binding to TNF-R on PMN.
Evaluation of the expression of CD11a, CD11b and CD18 molecules of LFA-1 and Mac-1 intregine and $\mathrm{CD} 10$ and $\mathrm{CD} 13 \mathrm{Ag}$ of neutral endopeptidase (NEP) and aminopeptidase $\mathrm{N}$ (APN) on PMN

The determination of molecule expressions on the surface of PMN was performed in the whole blood. Techniques, generally used for immunofluorescent labelling of the cells in whole blood collected on heparin, were applied. One hundred $\mu$ l of blood was mixed and incubated at room temperature with appropriate quantities of monoclonal antibodies, provided by Dako (Denmark). CD11a, CD11b and CD18 antibodies were used. A double-step staining procedure was used for the evaluation of CD10 and CD13 Ag expression. Mouse immunoglobulins antiCD10 and CD13 (Dako) were used as a first step. Rabbit anti-mouse IgG polyclonal immunoglobulins $G$ stained with R-phycoerythrin were used as a secondary antibody. Mouse IgG2a, stained with RPE, was used as a negative control. Erythrocytes were eliminated by an addition of lysing solution (Becton Dickinson) into the blood samples. After a short time of incubation and rinsing, the cells were suspended in physiological buffered saline (PBS). FACscan flow cytometer with a $488 \mathrm{~nm}$ argon laser (Becton Dickinson) and Lysis II software were used. The results were expressed as the values of MFI of the labelled surface antigens.

\section{Results}

The MFI of the PMN incubated with FITC-TNF was highest in the group with exacerbation of RR-MS (REL) (Table 1) and the value was significantly higher $(P<0.01)$ compared with the other groups of MS patients and to OND. In the course of CP-MS and in MS remission (REM) the tested values were in the range observed in the control group (OND).

Expression of CD10, CD13 Ag and CD11b/CD18 molecules on PMN was significantly increased in REL $(P<0.05$ and $P<0.01)$ compared $w$ ith that examined in CP-MS, REM and OND (Table 1). CD11a expression on PMN in REL was the same as in CP-MS patients and in OND. In the course of CP-MS only expressions of CD11b and CD18 but not CD10 and CD13 were significantly increased $(P<0.01$ and $P<0.05)$ compared with OND. Expressions of CD11a, CD11b and CD10 were markedly diminished $(P<0.01$ and $P<0.05)$ during remission of MS compared with the controls (Table 1).

\section{Discussion}

It has been proved in previous studies that there is a more intensive inflammatory response in acute exacerbations of RR-MS patients than in the course of 
Table 1. Mean fluorescence intensity (MFI) of fluorescein isothiocyanate (FITC) labelled TNF binding to polymorphonuclear neutrophils (PMN) and the CD10, CD13 Ag, and CD11a, CD11b, CD18 molecule expression on PMN in patients with relapsing-remitting MS during exacerbation (REL) (1), in chronic progressive MS (CP-MS) (2) during remission (REM) of the disease (3) and in the other neurological diseases (OND) (4)

\begin{tabular}{|c|c|c|c|c|c|c|}
\hline & $\begin{array}{l}\text { MFI of TNF-FITC } \\
\text { binding }\end{array}$ & $\begin{array}{l}\text { CD10 } \\
\text { expression }\end{array}$ & $\begin{array}{c}\text { CD13 } \\
\text { expression }\end{array}$ & $\begin{array}{l}\text { CD11a } \\
\text { expression }\end{array}$ & $\begin{array}{l}\text { CD11b } \\
\text { expression }\end{array}$ & $\begin{array}{l}\text { CD18 } \\
\text { expression }\end{array}$ \\
\hline $\begin{array}{l}\text { 1. REL } \\
(n=12)\end{array}$ & $\begin{array}{l}134.6 \pm 17.3 \text { range: } \\
115.8-151.6 \\
1 \text { vs. } 2 P<0.01 \\
1 \text { vs. } 3 P<0.01 \\
1 \text { vs. } 4 P<0.01\end{array}$ & $\begin{array}{l}52.7 \pm 10.7 \text { range: } \\
38.7-69.8 \\
1 \text { vs. } 2 P<0.05 \\
1 \text { vs. } 3 P<0.01 \\
1 \text { vs. } 4 P<0.01\end{array}$ & $\begin{array}{l}138.6 \pm 20.8 \text { range: } \\
126.4-168.8 \\
1 \text { vs. } 2 P<0.05 \\
1 \text { vs. } 3 P<0.01 \\
1 \text { vs. } 4 P<0.01\end{array}$ & $\begin{array}{l}70.7 \pm 12.0 \text { range: } \\
51.5-94.7 \\
1 \text { vs. } 3 P<0.01\end{array}$ & $\begin{array}{l}942 \pm 56 \text { range: } \\
827-1010 \\
1 \text { vs. } 2 P<0.01 \\
1 \text { vs. } 3 P<0.01 \\
1 \text { vs. } 4 P<0.01\end{array}$ & $\begin{array}{l}280.9 \pm 39.9 \text { range: } \\
210.1-347.1 \\
1 \text { vs. } 3 P<0.01 \\
1 \text { vs. } 4 P<0.01\end{array}$ \\
\hline $\begin{array}{l}\text { 2. } \text { CP-MS } \\
(n=12)\end{array}$ & $\begin{array}{l}119.1 \pm 14.5 \text { range: } \\
98.6-144.2\end{array}$ & $\begin{array}{l}42.9 \pm 13.9 \text { range: } \\
29.4-76.2 \\
2 \text { vs. } 3 P<0.01\end{array}$ & $\begin{array}{l}124.1 \pm 29.6 \text { range: } \\
87.2-174.2\end{array}$ & $\begin{array}{l}70.4 \pm 9.1 \text { range: } \\
58.2-81.2 \\
2 \text { vs. } 3 P<0.05\end{array}$ & $\begin{array}{l}743 \pm 114 \text { range: } \\
622-968 \\
2 \text { vs. } 3 P<0.01 \\
2 \text { vs. } 4 P<0.05\end{array}$ & $\begin{array}{l}277.2 \pm 30.9 \text { range: } \\
221.2-308.7 \\
2 \text { vs. } 3 P<0.01 \\
2 \text { vs. } 4 P<0.01\end{array}$ \\
\hline $\begin{array}{l}\text { 3. } \text { REM } \\
(n=13)\end{array}$ & $\begin{array}{l}112.0 \pm 15.2 \text { range: } \\
89.4-141.2\end{array}$ & $\begin{array}{l}23.8 \pm 2.6 \text { range: } \\
20.4-27.6 \\
3 \text { vs. } 4 P<0.05\end{array}$ & $\begin{array}{l}115.2 \pm 13.6 \text { range: } \\
89.4-140.8\end{array}$ & $\begin{array}{l}56.5 \pm 13.3 \text { range: } \\
31.2-84.1 \\
3 \text { vs. } 4 P<0.05\end{array}$ & $\begin{array}{l}483 \pm 166 \text { range: } \\
278-760 \\
3 \text { vs. } 4 P<0.01\end{array}$ & $\begin{array}{l}197.5 \pm 42.1 \text { range: } \\
162.1-286.4\end{array}$ \\
\hline $\begin{array}{l}\text { 4. OND } \\
(n=14)\end{array}$ & $\begin{array}{l}110.4 \pm 7.5 \text { range: } \\
94.5-121.6\end{array}$ & $\begin{array}{l}37.8 \pm 13.6 \text { range: } \\
20.6-67.2\end{array}$ & $\begin{array}{c}106.9 \pm 17.1 \text { range: } \\
80.2-148.2\end{array}$ & $\begin{array}{l}69.7 \pm 14.7 \text { range: } \\
52.7-94.6\end{array}$ & $\begin{array}{l}610 \pm 100 \text { range: } \\
460-728\end{array}$ & $\begin{array}{l}184.5 \pm 45.7 \text { range: } \\
127.4-274.2\end{array}$ \\
\hline
\end{tabular}

CP-MS. ${ }^{2}$ The obtained data suggest that relapsingremitting MS follows cycles of immunological activation as a result of Th- 1 response (exacerbation), which is then followed by a suppressor response that dow nregulates inflammation (remission). ${ }^{1,2}$ In CP-MS there is continuous low-grade inflammation with no obvious exacerbations or remissions.

The involvement of TNF in immunopathological processes in MS has already been known for quite some time. ${ }^{14}$ This cytokine is also one of the most potent priming factors for PMN in vitro. ${ }^{7,15} \mathrm{We}$ suggest that serum TNF of patients with acute exacerbations of RR-MS or in lower degree in the course of CP-MS can be the main priming factor of PMN.

TNF in vitro stimulates the expression of many of the PMN surface molecules. Simultaneously TNF stimulates its own receptors expression (TNF-R) on PMN. ${ }^{16}$ This has been confirmed in our study as the increased TNF binding to PMN in the course of acute exacerbations of MS. We have observed also the significant increase of the CD10, CD13 Ag and CD11b/CD18 molecule expression on PMN of MS patients, mainly in the course of exacerbation compared with MS remission and with OND groups. This may be a sign of priming of PMN in MS exacerbation and to a lower degree in the course of CP-MS.

Podikoglou et $a{ }^{3}{ }^{3}$ have shown that the typical functions of PMN, like adherence, chemotaxis, phagocytosis or bactericidal action have been significantly diminished in PB of MS patients. The results that we have obtained in our study correspond w ith Goto et al.. ${ }^{17}$ In some earlier observations Aoki et al. ${ }^{18}$ and Guarnieri et al. ${ }^{19}$ have shown that the increased intracellular neutral proteinase and medullasine concentrations can be the symptom of PMN activation in the blood of patients with acute exacerbation of MS.

PMN contain large amounts of proteinases, like NEP and APN, in their intracellular granules. ${ }^{20,21}$ The increased expression on in vitro stimulated PMN is a result of rapid translocation of an intracellular pool to the cell surface. ${ }^{22,23}$ The increased expression of CD11b/CD18-Mac-1 molecules probably results from their rapid shift from internal granules to the surface of primed PMN. Such process has not been observed in CD11a/CD18 molecules of LFA-1 integrine expression of in vitro primed PMN. ${ }^{24,25}$ In our studies we have not noticed the increased expression of CD11a molecule on PMN of MS patients w ith acute exacerbations or in the course of CP-MS. In our opinion, these can suggest PMN priming in patients with active MS. Activated PMN can produce oxygen and nitrogen species, some matrix degrading metalloproteinases and some cytokines. ${ }^{5,26}$ Priming is a preliminary event before receptor-induced stimulation of PMN. It is then a sign of these cells' hyperreactivity. PMN priming features observed in the $\mathrm{PB}$ of patients with active MS suggest that these cells may participate in the MS immunopathology.

\section{References}

1. Hohlfeld R, Meinl E, Weber F, et al. The role of autoimmune T lymphocytes in the pathogenesis of multiple sclerosis. Neurology 1995 : 45; (suppl 6); S33-S38.

2. Giovannoni G, Hartung HP. The immunopathogenesis of multiple sclerosis and Guillain-Barré syndrome. Curr Opin Neurol 1996: 9; $165-177$.

3. Podikoglou DG, Lianou PE, Tsakanikas CD, Papavassiliou JT. Polymorphonuclear leukocyte functions and multiple sclerosis. Neurology 1994: 44; 129-132.

4. Gadd SJ, Eher R, Majdic O, Knapp W. Signal transduction via Fc $\gamma$-R and Mac-1 $\alpha$-chain in monocytes and polymorphonuclear leukocytes. Im $m u$ nology 1994: 81; 611-617.

5. Cassatella MA. The production of cytokines by polymorphonuclear neutrophils. Im munol Today 1995: 16; 21-29. 
6. Mc Coll SR, Beauseigle D, Gilbert C, Naccache PH. Priming of the human neutrophil respiratoty burst by granulocyte-macrophage colony stimulating factor and tumor necrosis factor- $\alpha$ involves regulation at a post-cell surface receptor level: enhancement of the effect of agents which directly activate G proteins. J Im munol 1990: 145; 3047-3052.

7. Asman B, Gustafsson A, Bergstrom K. Priming of neutrophils with tumor necrosis factor $\alpha$ measured as $F_{c} \gamma$ receptor-mediated respiratory burst correlates with increased complement receptor 3 membrane density. Int $J$ Clin Lab Res 1996: 26; 236-239.

8. Condliffe AM, Chilvers ER, Haslett C, Dransfield I. Priming differentially regulates neutrophil adhesion molecule expression/function. Im munology 1996: 89; 105-111.

9. Monk PN, Barker MD, Partridge LJ. Multiple signalling pathways in the C5a-induced expression of adhesion receptor Mac-1. Biochim Biophys Acta 1994: 1221; 323-329.

10. Jagels MA, Chambers JD, Arfors KE, Hugli TE. C5a and tumor necrosis factor- $\alpha$ induced leukocytosis occurs indenpendently of $\beta 2$ integrins and L-selectin: differential effects on neutrophil adhesion molecule expression in vivo. Blood 1995: 85; 2900-2909.

11. Poser CM, Paty DW, Scheinberg L, et al. New diagnostic criteria for multiple sclerosis: guidelines for research protocols. Ann Neurol 1983: 13; $227-231$.

12. Kurtzke JF. Rating neurologic impairment in multiple sclerosis: an expanded disability status scale (EDSS). Neurology 1983: 33; 1444-1452.

13. Shirakawa F, Tanaka Y, Ota T, Suzuki H, Eto S, Yamashita U. Expression of interleukin 1 receptor on human peripheral T cells. J Im munol 1987: 138; 4243-4248.

14. Hartung HP, Archelos JJ, Zielasek J, et al. Circulating adhesion molecules and inflammatory mediators in demyelination: a review. Neurology 1995: 45 (suppl 6); S22-S32.

15. Klein JB, Scherzer JA, Harding G, Jacobs AA, McLeish KR. TNF-o stimulates increased plasma membrane guanine nucleotide binding protein activity in polymorphonuclear leukocytes. I Leukocyte Biol 1995: 57; 500-509.

16. Lantz M, Bjornberg F, Olsson I, Richter J. Adherence of neutrophils induces release of soluble tumor necrosis factor receptor forms. J Immunol 1994: 152; 1362-1369.

17. Goto I, Shinno N, Kuroiwa Y. Proteolytic enzyme activities in mononuclear cells and granulocytes of patients with various neurological disorders. J Neurol Sci 1983: 59; 323-329.
18. Aoki Y, Miyatake T, Shimizu N, Yoshida M. Medullasin activity in granulocytes of patients with multiple sclerosis. Ann Neurol 1984: 15; $245-249$.

19. Guarnieri B, Lolli F, Amaducci L. Polymorphonuclear neutral protease activity in multiple sclerosis and other diseases. An n Neurol 1985: 18; 620-622.

20. Casale L, Cardozo C, Kalb T, Lesser M. Quantitation of endopeptidase 24.11 and endopeptidase 24.15 in human blood leukocytes. Enzyme Prote in 1994/95: 48; 143-148.

21. Riemann D, Kehlen A, Thiele K, Lohn M, Langner J. Induction of aminopeptidase-N/CD13 on human lymphocytes after adhesion to fibroblast-like synoviocytes, endothelial cells, epithelial cells, and monocytes/macrophages. J Im m unol 1997: 158; 3425-3432.

22. Werfel T, Sonntag G, Weber MH, Gotze O. Rapid increases in the membrane expression of neutral endopeptidase (CD10), aminopeptidase $\mathrm{N}$ (CD13), tyrosine phosphatase (CD45) and Fc $\gamma$-RIII (CD16) upon stimulation of human peripheral leukocytes with human C5a. J Immunol 1991: 147; 3909-3914.

23. Connely JC, Chamblers R, Holiday D, Chittenden K, Johnson AR. Upregulation of neutral endopeptidase (CALLA) in human neutrophils by granulocyte-macrophage colony-stimulating factor. J Leukocyte Biol 1993: 53; 685-690.

24. Lo SK, Detmers PA, Levin SM, Wright SD. Transient adhesion of neutrophils to endothelium. J Exp Med 1989: 169; 1779-1793.

25. Zeman K, Kantorski J, Paleolog E, Feldmann M, TchUrzewski H. The role of receptors for tumor necrosis factor-a in the induction of human polymorphonuclear neutrophil chemiluminescence. Immunol Let 1996: 53; 45-50.

26. We iss SJ. Tissue destruction by neutrophils. N Engl J Med 1989: 320; $365-376$.

ACKNOWLEDGEMENTS. The authors would like to thank Professor Wojciech Stec and Dr Bońena Szymańska from the Department of Bioorganic Chemistry Polish Academy of Science, Lódź.

This work was supported by a Grant No. 4 PO5A 10009 from the State Committee for Scientific Research, Poland (KBN).

\section{Received 27 May 1998; accepted in revised form 31 August 1998}




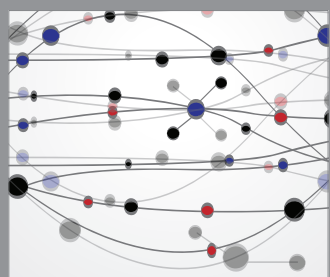

The Scientific World Journal
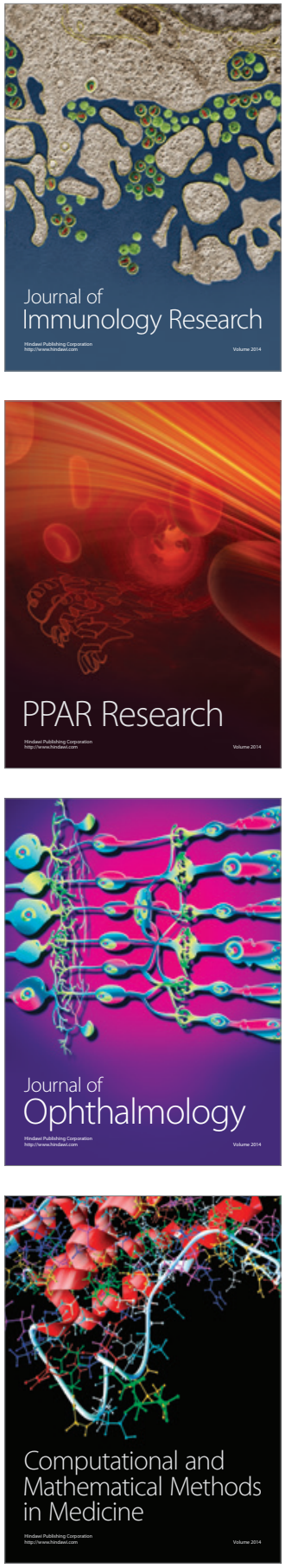

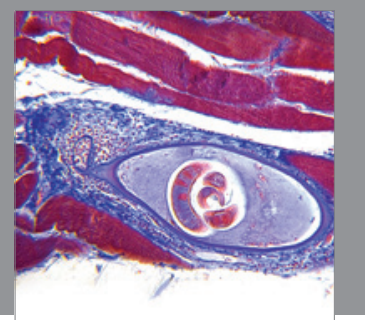

Gastroenterology

Research and Practice
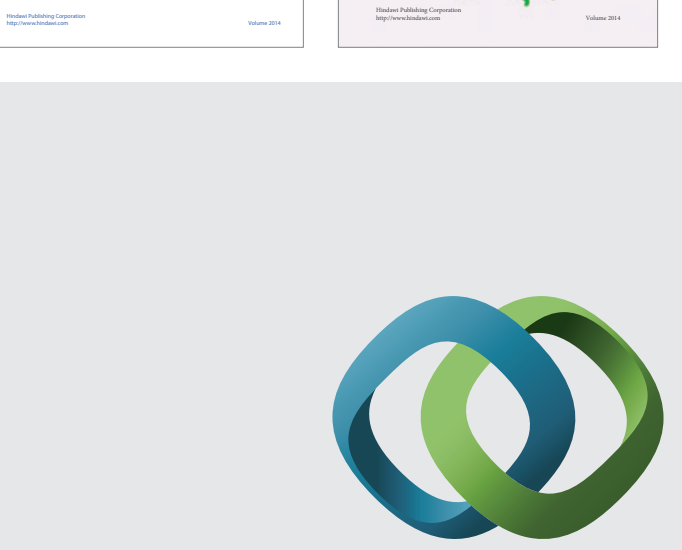

\section{Hindawi}

Submit your manuscripts at

http://www.hindawi.com
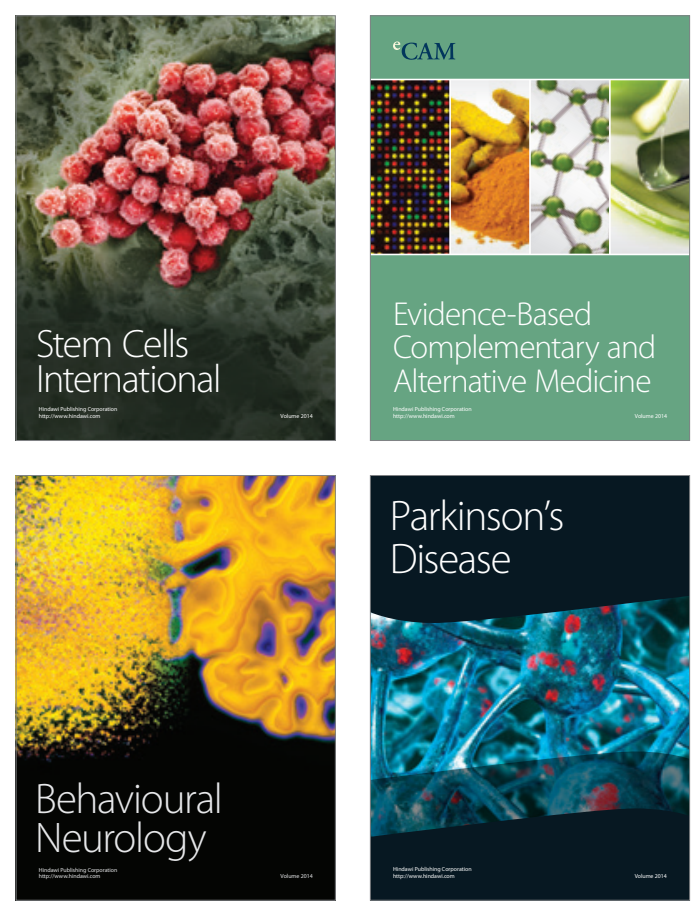

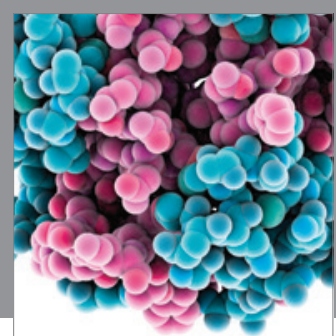

Journal of
Diabetes Research

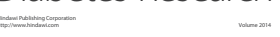

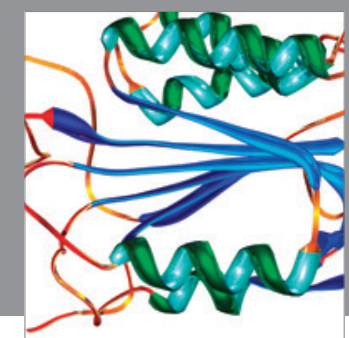

Disease Markers
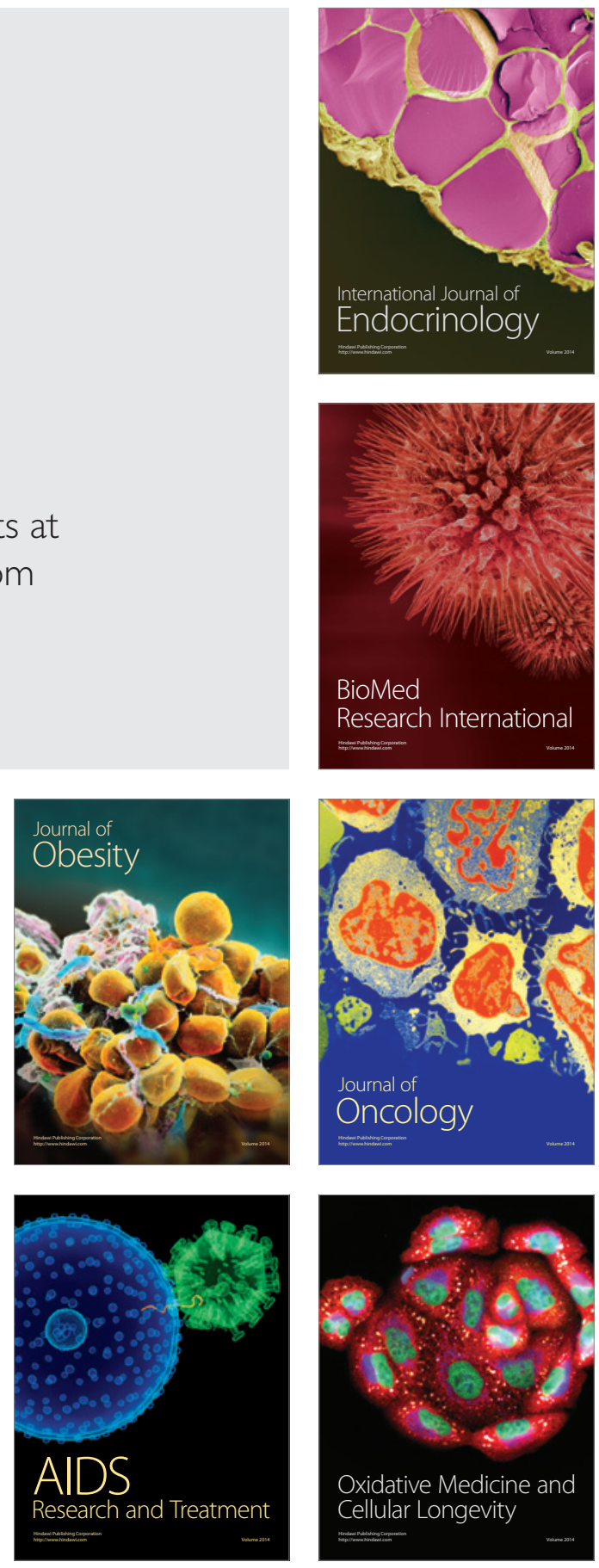